\title{
Reconstruction of the Determination of Collateral Object Auction Price in Indonesia Based on Justice Value
}

\author{
Moh Djarkasih $^{1^{*}}$, Gunarto $^{2}$, Anis Mashdurohatun ${ }^{2}$, Muhammad Ngazis ${ }^{2}$ \\ ${ }^{1}$ Doctorate Student of Faculty of Law Sultan Agung Islamic University Semarang, Indonesia \\ ${ }^{2}$ Faculty of Law Sultan Agung Islamic University Semarang, Indonesia
}

DOI: $\underline{10.36348 / \text { sijlcj.2020.v03i12.003 }}$

| Received: 19.11 .2020 | Accepted: 03.12.2020 | Published: 07.12.2020

*Corresponding author: Moh Djarkasih

Abstract

This research aim is to examine and analyze the weaknesses of the implementation of the auction execution of the object of the Mortgage especially in determining the auction price which is not yet based on Justice Value to then create a reconstruction of the execution auction of the Guarantee Rights in determining the auction price based on justice value. This research uses the method of empirical juridical approach where the data used in this study are primary data and secondary data, using qualitative analysis. The results showed that the weaknesses can be seen in Law no. 4 of 1996 concerning Mortgage Rights on Land and Objects Related to Land and Article 43 and Article 44 of the Minister of Finance Regulation No.27 / PMK.06 / 2016 concerning the Implementation Guidelines for Auction in determining the limit value made by an independent appraiser is in fact without any supervision by the supervisory agency for that and also without clear regulations regarding how to determine the auction price / auction limit value. To be able to resolve this, it is necessary to reconstruct the execution of the guarantee of the Guarantee Rights in determining the auction price based on Justice Value, namely in Article 6 and Article 20 paragraph (2) of Law No. 4 of 1996 concerning Mortgage Rights for Land and Objects Related to Land and Article 43 and Article 44 of the Minister of Finance Regulation No. the debtor and the creditor and if the auction price is not agreed upon, the settlement regarding the determination of the auction price shall be settled through the court so that the determination of the auction price can met the justice value.

Keywords: Auction, Collateral Object, Justice Value.

Copyright $\odot$ 2020 The Author(s): This is an open-access article distributed under the terms of the Creative Commons Attribution 4.0 International License (CC BY-NC 4.0) which permits unrestricted use, distribution, and reproduction in any medium for non-commercial use provided the original author and source are credited.

\section{INTRODUCTION}

Law No. 4 of 1996 concerning Mortgage Rights and Objects related to Land in addition to Minister of Finance Regulation Number 27 / PMK.06 / 2016 concerning Instructions for Conducting Auction regulates the procedure for executing the auction for the execution of the object of the Mortgage especially in determining the auction price. However, according to the author, this Law is not yet based on Justice Values because if there is a dispute regarding the determination of the auction price regarding the problem of determining a very low limit value, there is rarely a consideration from the judges, because judges usually only focus on formal legality, in this case, what is seen is a description of "is the auction implementation in accordance with the regulations?", namely regarding the completeness and legality of the documents, and if there is a question about the auction price, this is only considered as an attempt by the debtor to delay or prevent the auction from being carried out immediately [1].
It is a fact, that the determination of the limit value will affect the selling price of the object in question, because if it is sold at a good price, the debtor may get a return from the selling price that has been deducted from his credit debt, so that he can survive (do another business) with the money.

The determination of the auction price is one of the important steps for the realization of a good and just auction because debtors who forcibly lose their land must lose their land in order to fulfill their obligations. However, in practice, the auction price often becomes problematic, when the determined price (auction price/limit value) is too low and is not shown in any audit process regarding the accountable results of the assessment. Although the Regulation of the Minister of Finance Number 27 / PMK.06 / 2016 concerning Guidelines for Auction Implementation determines that the lowest auction price is the liquidation value, it is not a problem or it does not violates the law, if the set price is lower than the market price. However, from the above case example, in the trial, the auction price has 
never had special attention. The Bank will only focus on determining that the debtor is in default and the auction is legal. Likewise with the panel of judges, only seeing that there has been a default and the auction that has met the requirements is legal [2].

How the methods or criteria used or applied by the appraiser in determining the auction price cannot be demonstrated during the inspection process. This becomes the question: is the determination or method used appropriate and not detrimental to anyone?

The laws and regulations stipulate that the determination of this auction price must be accountable. However, from the cases above, neither bank can prove responsibility in determining the auction price. This is confusing, where the debtor inevitably has to accept the bank's decision in determining the price. Practices like this can injure the sense of justice where the purpose of holding an auction is to protect the debtor from arbitrary execution by the creditor. Therefore, it is necessary to have certain methods or criteria that have been regulated by law as a guide in determining the auction price, so as to be able to provide justice to the debtor.

However, it is different with the object of collateral for movable objects, namely those that are guaranteed by means of fiduciary security, as in the implementation of Article 15 paragraph (2) and paragraph (3) of Law No. 42 of 1999 regarding the Fiduciary Guarantee has been carried out by a Judicial Review as the decision of the Constitutional Court of the Republic of Indonesia Number 18 / PUU-XVII / 2019, dated January 6, 2020, in which case the implementation of the Fiducia guarantee requires an agreement of both parties, namely the debtor and creditor or through court decisions, also in determining a breach of contract (default) must also be agreed by both parties, or through a court stating that there is a breach of contract (default), this could be a reference for reconstructing the auction execution of the object of guarantee of security rights in determining the the value of justice.

This problem is what urges the author to study it further in a research with the following issues:

1. What are the weaknesses that arise in determining the collateral goods auction price in Indonesia currently?

2. How is the reconstruction of the determination of the collateral goods auction price in Indonesia based on Justice Values?

\section{METHOD OF RESEARCH}

The paradigm that is used in the research this is the paradigm of constructivism which is the antithesis of the understanding that lay observation and objectivity in finding a reality or science knowledge [3]. Paradigm also looked at the science of social as an analysis of systematic against Socially Meaningful Action through observation directly and in detail to the problem analyzed.

The research type used in writing this paper is a qualitative research. Writing aims to provide a description of a society or a certain group of people or a description of a symptom or between two or more symptoms.

Approach method used in this research is Empirical-Juridical [4], which is based on the norms of law and the theory of the existing legal enforceability of a law viewpoint as interpretation.

As for the source of research used in this study are:

1. Primary Data, is data obtained from information and information from respondents directly obtained through interviews and literature studies.

2. Secondary Data, is an indirect source that is able to provide additional and reinforcement of research data. Sources of secondary data in the form of: Primary Legal Material and Secondary Legal Materials and Tertiary Legal Material.

In this study, the author use data collection techniques, namely literature study, interviews and documentation where the researcher is a key instrument that is the researcher himself who plans, collects, and interprets the data [5]. Qualitative data analysis is the process of searching for, and systematically compiling data obtained from interviews, field notes and documentation by organizing data into categories, describing it into units, synthesizing, compiling into patterns, selecting important names and what will be studied and make conclusions.

\section{RESEARCH RESULT AND DISCUSSION Weaknesses That Arise In Determining the Collateral Goods Auction Price in Indonesia Currently}

In the implementation of a credit agreement, the implementation of the agreement, in general, should be followed in good faith. Good faith as conveyed by Samuel Hutabarat [6], namely a good faith at the time of making an agreement, means that a person with good intentions puts full trust in the opponent, which he considers, to be honest, and does not hide anything bad, which will later create difficulties. In short, the application of good faith in the implementation of an agreement is meant so that the agreement is carried out honestly, cleanly, and openly, so as to provide legal certainty, protection, and justice.

Furthermore, the seller's authority regarding the auction is one of which is given the right to determine the auction limit value which will affect the auction price. Creditors when acting as sellers must not be arbitrary in determining the limit value. The determination of the limit value must also be based on 
good faith, so that the objectives and purposes of articles 6 and 20 of Law No. 4 of 1996 concerning Mortgage Rights and Objects related to Land are fulfilled, namely:

1. Creditors can collect their receivables

2. The debtor can get the highest price for the object of the mortgage and can get the remainder of the sale.

However, unfortunately, the determination of the limit value by creditors often creates disputes or resistance from debtors because the results of auction sales are at a low price so that the goal of "getting the highest price" is not fulfilled or even becomes an ambiguous clause [7].

The resistance of this problem, for example, is in the case of the First Level Decision Number 55/Pdt.G/2016/PN.Pbr on 28 September 2016, where the debtor makes a loan/credit facility of IDR $250,000,000.00$ (two hundred and fifty million rupiahs) with collateral in the form of a plot of land measuring $211 \mathrm{~m} 2$ along with a house. After bad credit and must be executed, the amount of the debtor's debt repayment obligation is Rp. 328,540,540.62 (three hundred twentyeight million five hundred forty-eight thousand five hundred forty point six two rupiahs). The execution of the object of the mortgage was successfully carried out through an auction with an auction price of Rp. 344,250,000 (three hundred forty-four million two hundred and fifty thousand rupiah). Where, according to the creditor's statement, the auction has been conducted twice, namely the first auction on 15 October 2015 with a limit of IDR 550,000,000 (five hundred and fifty million rupiahs) and the second auction of a limit reduction, up to $337,000,000$ three hundred thirty-seven million rupiah), while the NJOP of the land is IDR $587,504,000$, so that normally the land should be sold at a price $(221 \mathrm{~m} 2 \times$ IDR 587,504,000), namely IDR $129,838,384$ (one hundred twenty-nine million eight hundred and thirty-eight thousand three hundred and eighty-four rupiah). If it is not sold at the first auction and must use the liquidation value in the limit value, then according to the Indonesian Public Appraiser (PPI) the land liquidation value is $70 \%$ of the market value, so that in this case, the land liquidation value is $70 \% \mathrm{x}$ Rp 129,838,384, namely Rp. 90,886,868 (ninety million eight hundred and eighty-six thousand eight hundred and sixty-eight rupiah)

Based on this case, the debtor's right to obtain the highest price in the sale through auction is not fulfilled. There is no regulation in articles 6 and 20 of Law No. 4 of 1996 concerning Mortgage Rights and Objects related to Land are fulfilled in relation to the standard for determining the auction price and the standard for decreasing the limit value in every auction, making creditors as sellers not paying attention to the norm provisions for determining the lowest limit value is the liquidation value. As a result of the research that, in the practice of banking habits, if the object of the mortgage has been auctioned several times and has not been sold, then the limit value is determined, which is below the principal value of the debt, provided that it does not eliminate the outstanding principal of debt that has not been paid and does not eliminate the right to collect.

In order to tackle this problem, It is necessary to improve the provisions in Article 6 and Article 20 of Law No. 4 of 1996 concerning Mortgage Rights and Objects Related to Land related to the standard determination of limit values or designation of other laws and regulations in terms of determining limit values, so that the determination of limit values for the first time was not carried out arbitrarily according to banking standards or practices and it is appropriate for the creditor to confirm this to the debtor as the owner of the object regarding the limit value that has been determined. Likewise, when the second, third, and so on, it is appropriate to conform to the debtor when there is a decrease in the limit value, especially if the limit value has touched the liquidation value. This is intended so that there is a cross-check mechanism between debtors and creditors, in monitoring the determination of limit values which are not arbitrary, so that the purpose of obtaining the highest price through an auction can be fulfilled.

Based on the description above, in order for the agreement to be carried out honestly and cleanly, which becomes the signs in the implementation of an agreement, apart from the existing laws, it must also relate to the appropriateness and values that exist in society, because good faith and The values of propriety are an important series needed in the implementation of an agreement.

The Supreme Court once decided on March 11, 1955 regarding the use of good faith in implementing an agreement with the consideration that this good faith can be done and in accordance with a sense of justice, so that in this case the contents of an agreement are not only determined by the parties to be bound by the agreement. it is determined also by good faith and propriety. In addition, Hoge Raad 19 May 1967, Arrest Saladin/HUB in good faith can rule out an agreement, meaning that good faith is an element of addition (aanvullend) the provisions of the agreement, besides that it also functions to limit and even cancel the provisions in the agreement when the agreement was executed.

The conclusion is that the application of good faith (acting honestly, properly, and not arbitrarily) is an effort to provide certainty and fairness to the parties. Therefore, the application of good faith for creditors and debtors is very important in determining the course of credit. 
Next, the second weakness is that the limit value is important because the limit value becomes the minimum standard for bidding in the auction process, it could be that the auction price is the limit price. Therefore, the limit value will affect the bid and will determine the auction price that occurs. In view of the fact that many lawsuits have been filed due to low or unreasonable auction prices due to low limit values. In addition, the main purpose of having a limit value is to provide protection for debtors from auction sales at arbitrary prices by the creditor. Given that in the auction, the seller is the creditor.

Third, is the absence of supervision, especially for appraisers or appraisers in conducting appraisals or appraisals. In one auction implementation mechanism, the State Property and Auction Service Office (KPKNL) is only responsible for the extent of the documents provided by the creditor as the seller, provided that the documents are complete or incomplete. Therefore, there is no institution that oversees the material of the submitted documents.

Auctions are not just about providing protection for creditors and debtors. Auction as one of the creditor authorities in executing the object of guarantee of mortgage rights as intended in Article 6 of Law No. 4 of 1996 concerning Mortgage Rights and Objects Related to Land is given so that credit settlement is no longer necessary through court. This is due to the mortgage certificate in which there is a foreword (irah-irah) written as "DEMI KEADILAN BERDASARKAN KETUHAN-AN YANG MAHA ESA" or "FOR JUSTICE BASED ON ONE ALMIGHTY GOD", which has the same power as a judge's decision. However, in practice, due to the absence of supervision, this objective was not carried out well, given a large number of challenges or challenges that have been submitted to the court regarding the auction.

This oversight needs to be regulated, either creating a special institution or giving the authority to KPKNL to examine the substance related to the determination of limit values. Keep in mind, the limit value is actually the seller's authority as seen in the popular term of the seller can sell however the price they want. However, it needs to be kept in mind, that the seller in the auction for the execution of the mortgage object is not the direct owner, but the creditor. Therefore, this supervisory agency must act as a control or carry out the function of checks and balances regarding the determination of the limit value to be determined in the auction.

The supervision itself can be in the form of rigid or clear laws and regulations, especially regarding the determination of limit and liquidation values, so that the parties concerned in checking the calculations have been carried out, either by internal parties of the bank or through appraisals.

\section{Reconstruction of the Determination of the Collateral Goods Auction Price in Indonesia Based On Justice Values}

The execution of the auction of the object of mortgage guarantee based on good faith and propriety basically depends on the process of determining the minimum limit value in the auction. This is because the limit value determines the bid and price of a later auction, as well as a trigger as a basis for claim or objection by the debtor but the regulations for the implementation of the auction do not specify how to evaluate the limit value yet. The regulations only stipulate that the limit value is carried out by an appraiser or appraiser, which is carried out by an accountable method.

The limit value is a predetermined value to be used in an auction bid, where the limit value can use the market value or the liquidation value, as an appraisal will produce 2 (two) numbers, namely the market value and the liquidation value. This matter, according to Wildan Suyuthi Mustofa, SH (Head of Education and Marine Affairs of the Supreme Court of the Republic of Indonesia) [8] it is said that: "determination of auction limit price considering NJOP (PBB) price, combined with market price is divided into 2 (two) as standard auction limit price". The explanation can be seen in the formula below:

Limit Value $\frac{\text { Sales Value of Tax Objects (NJOP) + Market Value }}{2}$

In practice, the determination of the minimum limit value referred to is not always carried out as stated by Wildan because not all estimators use this method in assessing. This can be seen from the opinion of the appraisal statements as a witness in the trial which stated "for other purposes the limit value is determined by a different method so that the results are different". According to Insulistiyono, NJOP from the kelurahan is not an element for valuing land. Even though the sale value of the tax object (NJOP) released by the district (Kelurahan) government can be used as a consideration for the market price at that time, while according to Salmon Marpaung [9] as a former KPKNL employee, it is stated that the market value of the auction object is determined by the price comparison, the price list released by the district government, NJOP and the appraiser must still go to the field to assess it. In addition, according to Raden Aditya as the appraisal, it is stated that the auction value is equal to $30 \%$ of the market value if it is still assessed above $30 \%$ or below $30 \%$ then it is still fine because it is an opinion and for comparative data, the assessment is the object around it 
which is less more than 100 meters to 300 meters from the appraised object as can be seen in the formula below:

Limit Value = Market Value $(+)(-\underline{30} \%$ Market Value

Then, according to Harwono [10], the limit value is determined in four stages, namely:

Limit value $=$ market value

Limit value $=$ liquidation value

Limit value $=$ principal amount of debt

Limit value $=$ below the principal amount of debt

The four stages are carried out sequentially. If the market value of the object has not been sold, the limit value will touch the liquidation value, up to the principal amount of the debt. The value of liquidation can be seen from the provisions of Articles 75 and 76 of the Regulation of the Minister of Finance Number 180 / PMK.06 / 2009 concerning the Assessment of Collateral Goods and/or other Assets in the context of Managing State Receivables by the State Receivables Affairs Committee/Directorate General of State Assets, namely by reducing market value with the amount of risk attached to the object of the appraisal and risk of sale through auction, the amount of risk used in determining the liquidation value is $30 \%$ (thirty percent) as can be seen in the formula below:

Value Limit $=$ Market Value - Risk $(30 \%$ of Market Value $)$

Some of the methods for assessing the aforementioned above show that the absence of regulations regarding standards regarding the method of determining the limit value results in different outcomes, almost as if it is in accordance with its interests. This is not to mention if the determination of the limit value is carried out by an estimator from the bank which has an interest in selling the object of the guarantee as soon as possible. Therefore, in the absence of regulations regarding the determination of limit values, and the possibility of interests, the application of the principle of good faith becomes questionable.

Such practices will be detrimental to debtors with good faith who voluntarily sell their land, but the application of the limit value is arbitrary, this raised question of whether justice goes to debtors with good faith or not as where does the limit value function as a protection for debtors is unknown. In particular, when the object of an auction must be sold below the cost of debt. Even though the auction regulations have been regulated in Article 49 PMK No.27/2016 that in the implementation of Article 6 mortgage law (UUHT) Execution Auction, Fiducia Execution Auction, and Bankruptcy Execution Auction, the Limit Value is determined to be at least the same as the Liquidation Value. Therefore, the lowest limit value is the liquidation value itself. However, this is not the case when the limit value is able to touch below the principal amount of the debt as this, of course, injures the purpose of the guarantee of land rights as a special guarantee that has the value of a security right to guarantee the fulfillment of the debt (principal) with the guarantee of the land rights.

Good faith in determining the limit value can be seen from the rationality of determining land prices. When a creditor estimates the value of the mortgage, then the creditor indirectly declares that he has the courage to buy the object of the mortgage at the amount of the mortgage in the year the mortgage is signed. The auction may be conducted after several months or maybe several years from the commencement of the agreement. In principle, the value of land does not experience depreciation, but on the contrary, it will continue to increase. Therefore, it is not in good faith, when the creditor places a standard valuation on the land value when the object of the mortgage is granted.

Legislation related to the implementation of the auction for the execution of the object of guarantee of mortgage has indeed accommodated all the activities or formal and material processes required. However, nowadays, the needs of the community are increasing and it affects the desire for credit from the community. Starting from credit offers with low-interest rates to credit offers without collateral, which are very tempting, but this is not followed by an increase in public knowledge regarding the risks that will occur. Therefore, the purpose of providing credit to improve living standards is the opposite, where most people lose their land rights as when the land becomes a strategic object in an effort to improve people's lives, it becomes the opposite. Therefore there need to be new efforts in overcoming this problem.

Good faith in the implementation of the agreement from pre-implementation to implementation greatly affects the auction. As previously explained, the regulation says that the lowest limit value is the liquidation value, but in practice, the lowest limit value is below the principal amount of the debt. This is because the land and building objects have the deficiencies previously described. Therefore, in assessing the pre-credit object, apart from taking into account the market price, the creditor must also calculate the depreciation of the building value when what is guaranteed is the land and buildings on it.

Besides the importance of good faith and prudence. In overcoming auction problems in order to provide a sense of fairness to all parties, especially with regard to limit values, it is necessary to renew existing laws and regulations. This is intended so that the determination of the limit value in the auction for the execution of the object of guarantee of security rights based on the value of justice. The value of fairness is 
defined as the existence of rigid and definite regulations in determining the limit value, starting from the standardization of the methods used, the factors that affect prices, transparency and education for interested parties related to auction sales, as well as the good faith of all parties involved. in the auction. Meanwhile, the renewal of legislation to be more rigid in regulating, namely:

1. That Article 6 of Law Number 4 of the Year 1996 concerning Mortgage Rights to Land and Objects Related to Land needs to be changed to: "If the debtor has defaulted, the first Mortgage holder has the right to sell the object of the Mortgage and take repayment of the debt. of the proceeds from the sale ".

2. Article 20 of Law No. 4 of 1996 concerning Mortgage Rights to Land and Objects Related to Land, must be amended to: (2). In the sale of the object of the Mortgage, it is necessary to have an agreement between the giver and the holder of the Mortgage in advance in terms of determining the selling price, whether it is carried out through a public auction or carried out under the hands and if the agreement as intended is not reached, then the settlement of the determination of the selling price is settled through the court with a lawsuit to determine the selling price.

3. Omitting Article 43 of the Minister of Finance Regulation No.27/PMK.06/2016 concerning the Auction Implementation Guidelines because it does not match the value of justice.

4. Article 44 of the Regulation of the Minister of Finance No.27/PMK.06/2016 concerning the Instructions for Conducting Auction plus 2 (two) paragraphs namely paragraph (5) and paragraph (6) which reads as follows:

5. The determination of the Limit Value as referred to in paragraph (1) must be agreed upon by the Debtor as the owner of the object of Mortgage.

6. If the agreement as referred to in paragraph (5) does not come to an end, then the settlement of the limit value determination shall be settled through a court with a lawsuit to determine the limit value/ its selling price.

\section{CONCLUSION}

1. Weaknesses that arise in the execution of the object of the guarantee of the mortgage in determining the auction price in Indonesia currently are due to the initial implementation of the credit which is carried out without heeding the principle of good faith. Debtors who do not have good intentions cooperate with individual creditors to increase the value of the insurance. Even though the debtor's ability does not exist, so that the credit score increases, which results in bad credit. Not to mention that because there is no institution that supervises appraisers or appraisers, it will have the potential to determine arbitrary limit values, without taking into account the potential of the land, the market value of the land, the condition of the land, and other things that affect the estimation, due to the interest of the creditors to be able to quickly. execute the mortgage guarantee object.

2. The reconstruction of the auction for the execution of the guarantee of the mortgage in determining the justice value-based auction price is carried out by making changes and placing justice as a goal and achievement. Therefore, there is a need for renewal of the laws related to the auction, especially in Article 20 of Law Number 4 of 1996 concerning Mortgage Rights to Land and Objects related to Land and Article 44 of the Minister of Finance Regulation (PMK) No.27 / PMK.06 / 2016 concerning the Instructions for Conducting Tender/Auction.

\section{REFERENCES}

1. Saputri, D. (2020). Perlindungan Hukum Terhadap Pembeli Lelang Dalam Pelaksanaan Lelang Eksekusi Hak Tanggungan. Pamulang Law Review. 2. 7. 10.32493/palrev.v2i1.5340.

2. Karina, A., \& Sukarmi, S., \& Kawuryan, E. (2020). Keabsahan Akta Risalah Lelang Sebagai Akta Otentik Dalam Pelaksanaan Lelang Elektronik Oleh Kantor Pelayanan Kekayaan Negara Dan Lelang. Jurisdictie. 11. 1. 10.18860/j.v11i1.7421.

3. Faisal. (2010). Menerobos Positivisme Hukum, Rangkang Education, Yogyakarta.

4. Johnny, I. (2005). Teori dan Metodologi Penelitian Hukum Normatif, Bayumedia, Surabaya.

5. Moleong, L. (2002). Metode Penelitian Kualitatif, PT Remaja Rosdakarya, Bandung.

6. Samuel, M. P. H. (2010). Penawaran dan Penerimaan dalam Hukum Perjanjian, Grasindo, Jakarta, 45.

7. Suharto, R. (2019). Lelang Eksekusi Hak Tanggungan. Law, Development and Justice Review. 2. 183-193. 10.14710/ldjr.v2i2.6315.

8. Supreme Court. (2011). Consideration of the Decision of the Supreme Court Number $2113 \mathrm{~K} /$ Pdt / 2010, dated 3 August 2011.

9. ibid.

10. Harwono. (2020). Interview, as the Field Collection Team Leader of PT. Bank Tabungan Negara, (Persero) Tbk Cirebon, on August 20, 2020 . 